\title{
Gamification and L2 vocabulary learning: The Vocabox Experience in the Languages without Borders Program
}

\author{
Janaina Weissheimer ${ }^{1}$ \\ Juliana Geizy Marques de Souza² \\ João Pedro Lobo Antunes ${ }^{3}$ \\ Neemias Silva de Souza Filho ${ }^{4}$
}

Programa de Pós-Graduação em Estudos da Linguagem, Universidade Federal do Rio Grande do Norte, Natal, RN, Brasil

\begin{abstract}
This study investigated a gamified vocabulary teaching and learning intervention, the Vocabox Experience, which was implemented in the context of the Languages without Borders. The research was developed collaboratively among the English teachers and coordinators, with classroom data being collected with 32 students by twelve teachers and one coordinator. The data were collected using an observation grid during classes and conducting two focal discussion sessions, one with the students and one with the teachers who implemented the games in their classes. The qualitative results indicate that both teachers and students see the Vocabox Experience as a significant learning opportunity, although teachers tend to see learning in a broader perspective while students tend to see it more as the memorization of new words. The quantitative data show that teachers preferred to use vocabulary games to warm up their classes and balanced both competition and collaboration elements when designing the games. As for the students, they showed more signs of engagement than disengagement, overall.
\end{abstract}

Keywords: Gamification; L2 vocabulary learning; Vocabox Experience; Languages without Borders.

Título: Gamificação e aprendizagem de vocabulário em L2: A Vocabox Experience no Programa Idiomas sem Fronteiras

Resumo: Este estudo investigou uma intervenção gamificada de ensino de vocabulário, chamada de Vocabox Experience, que foi implementada no contexto do programa Idiomas sem Fronteiras

\footnotetext{
${ }^{1}$ Doutora (UFSC), UFRN. Orcid: https://orcid.org/0000-0002-6318-4906

E-mail: janaina.weissheimer@gmail.com

${ }^{2}$ Mestranda (Universidade Federal do Rio Grande do Norte), UFRN. Orcid: https://orcid.org/0000-0002-4612-7520

E-mail: julianamrqs0@gmail.com

${ }^{3}$ Mestrando (Universidade Federal do Rio Grande do Norte), UFRN. Orcid: https://orcid.org/0000-0001-6308-0405

E-mail: pedro7lobo@gmail.com

${ }^{4}$ Mestrando (Universidade Federal do Rio Grande do Norte), UFRN. Orcid: https://orcid.org/0000-0002-6199-9431

E-mail: neemiassfilho@gmail.com
} 
(IsF). A pesquisa foi desenvolvida de forma colaborativa entre os professores e coordenadores do IsF, com dados sendo coletados com 32 alunos pelos doze professores de inglês e um coordenador. Os dados foram coletados por meio de uma grade de observação durante as aulas e duas sessões de discussão focal, uma com os alunos e uma com os professores que implementaram os jogos em suas aulas. Os resultados qualitativos indicam que professores e alunos vêem a Vocabox Experience como uma oportunidade significativa de aprendizado, embora os professores tendam a ver o aprendizado como um aspecto mais amplo, enquanto os alunos tendem a vê-lo mais como a memorização de novas palavras. Os dados quantitativos mostram que os professores preferiram usar os jogos de vocabulário como warm up em suas aulas e equilibram os elementos de competição e colaboração ao planejar e executar os jogos. Quanto aos alunos, eles mostraram mais sinais de engajamento do que desengajamento, em geral.

Palavras-chave: Gamificação; Aprendizagem de vocabulário em L2; Vocabox Experience; Idiomas sem Fronteiras.

\section{Introduction}

\section{Gamification and L2 learning}

Technological changes in society have led us to rethink common practices, such as vocabulary learning. Gamification has been a recurring proposal to promote individuals' cognitive engagement ${ }^{3}$ in diverse contexts (FADEL, L. M.; ULBRICHT, V. R.; BATISTA, C. R.; VANZIN, T., 2014). The term Gamification is defined by Deterding, Dixon, Khaled and Nacke (2012) as the use of game design elements in a non-game context. In other words, the principle of gamification is the appropriation of game and gaming elements applied to contexts, products and services not necessarily focused on games, but with the intention of promoting one's motivation and cognitive engagement (DETERDING et al., 2012). Examples of gamification range from the application of rewarding systems (such as points, emblems, levels, etc.) in social networks to the use of motivational elements in banks and stores, among other contexts, to encourage the public to use their services.

In the educational context, gamification has also been used, especially in recent years (ZICHERMANN, CUNNINGHAM, 2011; SEPEHR, HEAD, 2013; FADEL, ULBRICHT, BATISTA, VANZIN, 2014). Gamified experiences in the $L 2$ classroom include the use of digital applications such as duolingo.com and specific websites devoted to L2 vocabulary learning, such as vocabulary.com.

\footnotetext{
${ }^{3}$ In this study, the terms "cognitive engagement" and "motivation" are used interchangeably to refer to mental processes resulting from experiences lived by learners in the classroom, which cause retention of attention and sense of well-being.
} 
The mechanics of games, according to Zichermann and Cunningham (2011), is composed of several elements such as: points, levels, challenges and missions, reinforcement and feedback, surprise, fantasy, clear goals, among others. Competition and collaboration are also important and, in a certain way, indissociable aspects of the gamification scenario. Sepehr and Head (2013) claim that although the feeling of defeat (inherent to the game) has a negative effect on the satisfaction of learners, competition is nevertheless a key element that motivates learners to engage in playful activities. Collaboration, in turn, may lessen the burden of competition, since it provides an opportunity for learners to try to solve collective challenges around a common objective (VIANNA et al., 2013).

In addition, digital game designers have relied on the Theory of Flow (CSIKSZENTMIHALYI, 1990) for the construction of more immersive games, where the user "disconnects" from the outside world and begins to concentrate almost exclusively in the game. Lately, it has become more difficult to fulfill tasks with a certain degree of concentration, due to the immense amount of information, number of electronic devices, advertisement on websites and interaction in social networks. According to Fadel et al. (2014), an educational environment, therefore, should draw attention and focus learners on what is relevant. In this context, then, it is possible to use gamification as an alternative to provoke a feeling of satisfaction and well being in learners, boost their attention and concentration levels, and motivate them to carry out activities in class. To do so, we need to plan how, when, where and why to gamify our practice.

\section{L2 vocabulary learning}

There is a distinction between vocabulary teaching and vocabulary learning. Although there is evidence showing that teaching does not always equal learning, and only a portion of vocabulary is learnt through activities, deliberate learning retention rates exceed those from incidental learning, and some activities have better learning potential than others (NATION, 2001). Knowing which activities are best for each purpose can lead to a reduction of time spent in vocabulary teaching. Such time could be better invested in other relevant classroom tasks, such as reading, fluency development, and meaning-focused input and output activities (NATION, 2011).

Knowing a word well involves knowing several aspects covering its form, meaning and use. This can sometimes generate various degrees of learning burden (NATION, 2006) depending on, for example, the amount of cognate vocabulary the two languages share. Teachers can try to lighten the learning burden of words, which tends to be higher in the early 
stages of language learning, in several ways. One strategy commonly employed by teachers is to explicitly highlight similarities between vocabulary in the first and second languages and preteach features that will make the new words easier to learn (NATION, 2006). Another aspect teachers can draw students' attention to is how words collocate (i.e. typically occur together) in the language they've been learning. Although collocations are believed to be learned through extensive experience with the language, teachers can help learners develop strategies to store and retrieve chunks of language (LEWIS, 1997) in order to produce accurate language quickly.

The discussion of deliberate and intuitive vocabulary learning has been a great one in the applied linguistics area, specially because of the communicative approach, which has been largely adopted by the language teaching community. Nation (2011), however, suggests that deliberate learning of vocabulary speeds learners' progress towards an effective vocabulary size. However, the author also states that deliberate learning is just one step in the complex process of learning a word. It is important, then, to put forth that even though deliberate learning may be faster, incidental learning brings contextual aspects that are equally important when learning a word efficiently, and, therefore, one should not happen without the other.

Considering that words have to be manipulated and held in working memory before they can have a chance of entering long-term memory (i.e. be learnt), making certain features more salient for learners to focus attention on is a key element in effective vocabulary teaching. Working memory capacity restrictions place a limit to the amount of words that can be temporarily manipulated and stored (BADDELEY, 2000). Therefore, it is important for teachers to consider the optimal number of new words to be introduced to learners in each class, which should range between 5 and 9 (MILLER, 1956). In addition, words have a higher chance of retention in long-term memory if they are repeatedly encountered in class; therefore, it is important for teachers to include systematicity to their vocabulary teaching.

Nation (2011) points out that research into vocabulary teaching has increased extensively in the last several years. Current studies have also emphasized the importance of systematicity in vocabulary learning. Being exposed to a new word in class and not be given the opportunity of re-encountering that word seems to do a disservice to $L 2$ vocabulary learning. That being said, a prevailing question is whether the same words should be studied intensively for a period of time (massive learning) or they can be repeatedly studied for briefer periods of time at increasingly spaced intervals (distributed learning). Our study aims to tackle this issue by implementing a pedagogical intervention that involves the distributed learning of L2 vocabulary and assessing its effects.

With that in mind, this paper aims at reporting the results of a study which involved a gamified vocabulary intervention - The Vocabox Experience - in an L2 context. Our main goal 
was to relate the teachers' implementation of the gamified vocabulary tasks to their learners' reactions in terms of engagement and motivation, both qualitatively and quantitatively. The research questions guiding our study were: How do teachers implement the vocabox experience? How do learners react to such pedagogical implementation? How do teachers and learners perceive the outcomes of the vocabox experience? We intent, therefore, to assess how effective the Vocabox experience was, examining students' engagement and teachers' implementation of the pedagogical intervention in the classroom. Our ultimate aim is to contribute to the literature on gamification and L2 vocabulary teaching and learning, helping teachers build a broader repertoire of strategies to lessen the effects of vocabulary learning burden.

\section{Methods}

This study associates gamification and L2 vocabulary teaching and learning through the use of the Vocabox Experience, which was implemented in the context of the Languages without Borders (LwB) program ${ }^{4}$ at the Federal University of Rio Grande do Norte (UFRN) during the first semester of 2018. The research was developed collaboratively, with classroom data about the Vocabox implementation being collected by seven teachers and six observers, as described in the following sections. For these reasons, this study can be placed in the scope of action research as characterized by Nunan (1992). The study is considered to be quali-quantitative, since the collected data are both interpretative, such as students' and teachers' impressions, and numerical, such as results from observation grids.

\section{Context and participants}

This study was conducted by twelve teachers and one coordinator from the LwB program, and aimed to investigate the outcomes of the implementation of the pedagogical Vocabox Experience. The cohort also included thirty-two students enroled in the program. All participants signed a consent form authorizing the use of the data collected, including the recordings of their voices in the focused-discussion session.

\section{LwB teachers}

\footnotetext{
${ }^{4}$ Languages without Borders (LwB) is a program maintained by the Brazilian Ministry of Education. It promotes actions focused on language policies and internationalization in Brazilian institutions of higher education. Among these actions is the offer of English language classes designed to address academic needs, such as comprehension of lectures, speaking in daily interactions and preparation for proficiency exams.
} 
For the purpose of this research, the twelve LwB teachers were divided into two groups. Six of them constituted the first group - the vocaboxers - who would be responsible for 1) the implementation of the gamified experience in their classes and 2) the execution of a focused discussion with their students about the Vocabox Experience. Considering the process of observation as an important tool to investigate learning (WAJNRYB, 1992), the other half of the teachers were arranged to constitute the group of observers. They were responsible for developing an observation grid to be used in the subsequent stages of data collection. In this case, the observers were responsible for attending the classes and observing the use of gamification techniques in vocabulary learning through the Vocabox Experience, according to the aspects predetermined by the observation grid. This group also used the grid to collect data to be analyzed together with the focused discussion data. The focused discussion technique and the observation grid will be further detailed in section 2.2.

LwB Students

The participants of the study were 32 LwB students enrolled in 8-week-long Listening and Speaking courses. Their level ranged from A2 to B1 according to The Common European Framework of Reference for Languages. All of them were native speakers of Brazilian Portuguese and signed a Consent Form confirming that they accepted to participate as volunteers in this study.

Data collection instruments and procedures

\section{a) The gamified Vocabox Experience}

Each of the teachers used a box (any box-like container, handmade or not) as a Vocabox in their classrooms to add vocabulary that was new to their students throughout the course. All the words contained in the vocabox were class-generated and chosen by the students themselves, with the teachers' guidance. In the first stage, the teachers established a classroom goal regarding the number of words that should be added to their Vocabox (ranging from 5-9 words per class). Along the course, the words from Vocabox would be used in daily gamified tasks implemented to review the vocabulary, which accumulated along the classes. These tasks included a range of games or gamified activities (Table 1). Two weeks previous to the end of the course, the teachers were paired with six observers, who attended the teachers' classes. The observers collected data through an observation grid, especially designed for the purpose of this research. In the second stage, two focused discussion sessions were implemented: one led by 
the LwB coordinator with the teachers, and another led by each teacher and his/her respective students, to gather their impressions upon the effectiveness of the Vocabox Experience.

b) Instruments: observation grid and focused discussion session

The six observers were responsible for collecting data using an observation grid designed for this research. The grid was divided into aspects that should be considered by the observer when evaluating the Vocabox Experience in the classroom. Two sections were created to facilitate this investigation. Section I focused on the learners active participation and signs of engagement along the classes. Section II was destined to the strategies used by the teacher when using the Vocabox words along each class.

Two weeks after the observation, each vocaboxer implemented a focused discussion in their classes. This discussion aimed to gather the students impressions of the effects of the Vocabox Experience on their vocabulary learning experience. The students signed a consent allowing their comments to be recorded. They were asked to focus on positive and negative aspects of the Vocabox Experience.

Another focused discussion session happened with the LwB coordinator and the teachers who implemented the Vocabox Experience. This discussion aimed for the same type of feedback and each teacher gave their opinions on positive and negative aspects on the Vocabox Experience as a teaching technique. All sessions were conducted in Portuguese to allow a more natural account of participants' impressions, without getting proficiency limitations in the way.

Table 1: Gamified tasks and gaming elements

\begin{tabular}{|c|c|c|}
\hline Vocabox Game & Description & Gaming Elements \\
\hline Bananagrams & $\begin{array}{l}\text { The students were given a certain amount of } \\
\text { jumbled letters. They should put them together } \\
\text { to create a vocabox crossword. The one who is } \\
\text { able to set up more vocabox words, wins. }\end{array}$ & $\begin{array}{l}\text { Points, } \\
\text { reinforcement, } \\
\text { competition }\end{array}$ \\
\hline Hot potato & $\begin{array}{l}\text { The timer is set for a certain amount of time. In a } \\
\text { circle, Student A draws a word from the vocabox } \\
\text { and describes it to their colleagues. Student A } \\
\text { passes the stack to Student B when the other } \\
\text { gets the word and so on. The person holding the } \\
\text { vocabox when time is over, loses. }\end{array}$ & $\begin{array}{l}\text { Surprise, collaboration, } \\
\text { competition, mission }\end{array}$ \\
\hline Vocabulary jam & $\begin{array}{l}\text { The teacher should create a vocabulary jam on } \\
\text { vocabulary.com using the previously created } \\
\text { vocabulary list for the group in question. } \\
\text { Students should log in with their cellphones } \\
\text { entering vocab.com/jam and enter a code to } \\
\text { compete, either alone or in groups. }\end{array}$ & $\begin{array}{l}\text { Levels, challenges, } \\
\text { collaboration, competition, } \\
\text { feedback }\end{array}$ \\
\hline Acting out words on & Teacher writes down a vocabox word on a post-it & Points, levels, challenges and \\
\hline
\end{tabular}




\begin{tabular}{|c|c|c|}
\hline forehead & $\begin{array}{l}\text { and glues it on a student's forehead. The other } \\
\text { students should act out the word in order to } \\
\text { make the student with the post-it guess the } \\
\text { word. }\end{array}$ & $\begin{array}{l}\text { missions, reinforcement and } \\
\text { feedback, surprise, fantasy, } \\
\text { clear goals, competition, } \\
\text { collaboration }\end{array}$ \\
\hline Back massage & $\begin{array}{l}\text { Student A writes words on Student B's back. They } \\
\text { have to guess which word was written. }\end{array}$ & $\begin{array}{l}\text { Reinforcement, feedback, } \\
\text { surprise, fantasy, clear goals, } \\
\text { competition, collaboration }\end{array}$ \\
\hline Chain story & $\begin{array}{l}\text { Students improvise a story together using words } \\
\text { which have been drawn, one at a time, from the } \\
\text { Vocabox. }\end{array}$ & $\begin{array}{l}\text { Challenges and missions, } \\
\text { reinforcement and feedback, } \\
\text { surprise, fantasy, clear goals, } \\
\text { collaboration }\end{array}$ \\
\hline 11 & $\begin{array}{l}\text { The students start counting from } 1 \text { to } 11 \text {; each of } \\
\text { them says a number and the last one, number } \\
11 \text {, must change a number for a vocabox word. } \\
\text { Then, students count the numbers again and } \\
\text { should say the vocabox word instead of the } \\
\text { number when necessary. }\end{array}$ & $\begin{array}{l}\text { Competition, mission, } \\
\text { reinforcement, surprise, clear } \\
\text { goals, competition, } \\
\text { collaboration }\end{array}$ \\
\hline Drawing the words & $\begin{array}{l}\text { Teacher draws a word from the vocabox and } \\
\text { gives it to a student. The student should draw the } \\
\text { meaning of the word on the board and the other } \\
\text { students should try to guess what it is. The } \\
\text { student who guesses first, wins. }\end{array}$ & $\begin{array}{l}\text { Points, challenges, missions, } \\
\text { reinforcement and feedback, } \\
\text { surprise, fantasy, clear goals, } \\
\text { competition, collaboration }\end{array}$ \\
\hline
\end{tabular}

\section{Data analysis procedures}

Data from the focused discussion group sessions (students and teachers) were transcribed and analysed qualitatively, and results were displayed in word clouds using Wordle (http://www.wordle.net). Word clouds represent the frequency with which words are present in people's speech. The most frequent words are displayed in a larger font than the less frequent ones. Excerpts from teachers' and students' transcriptions were selected to illustrate the results generated by the word clouds. Data from the observation grids were analysed quantitatively, using the information in the observers' notes to design graphs.

\section{Results and Discussion}

In this section, we'll present the data and discuss them based on the literature reviewed in the introduction of this paper.

\section{An overview of the gamified Vocabox Experience implementation}

In order to present an overview of the Vocabox Experience, we designed the following graphs based on the data collected by the observers in class to illustrate: (a) when the 
vocabulary games were implemented; (b) who was responsible for choosing words (students, teachers or both); (c) signs of engagement among learners, and (d) signs of disengagement among learners.

Graph 1 shows that most games were implemented as warm ups, in the beginning of the class. The objective of a warm up game is to get students into the mood before starting a new class or content (UR; WRIGHT, 2007). The graph also reveals that fewer games were implemented in the end of the lessons and no vocabox game was implemented as a filler, in the middle of a lesson. These data suggest that teachers may see two main purposes in using vocabulary games: to engage students' attention and motivate them to what is next in class, and/or to revise knowledge acquired in previous lessons. In the case of the latter, the vocabox game is seen as a catalyst of pevious information, as a way to revise and potentialize prior learning.

Graph 1: when vocabox games were implemented

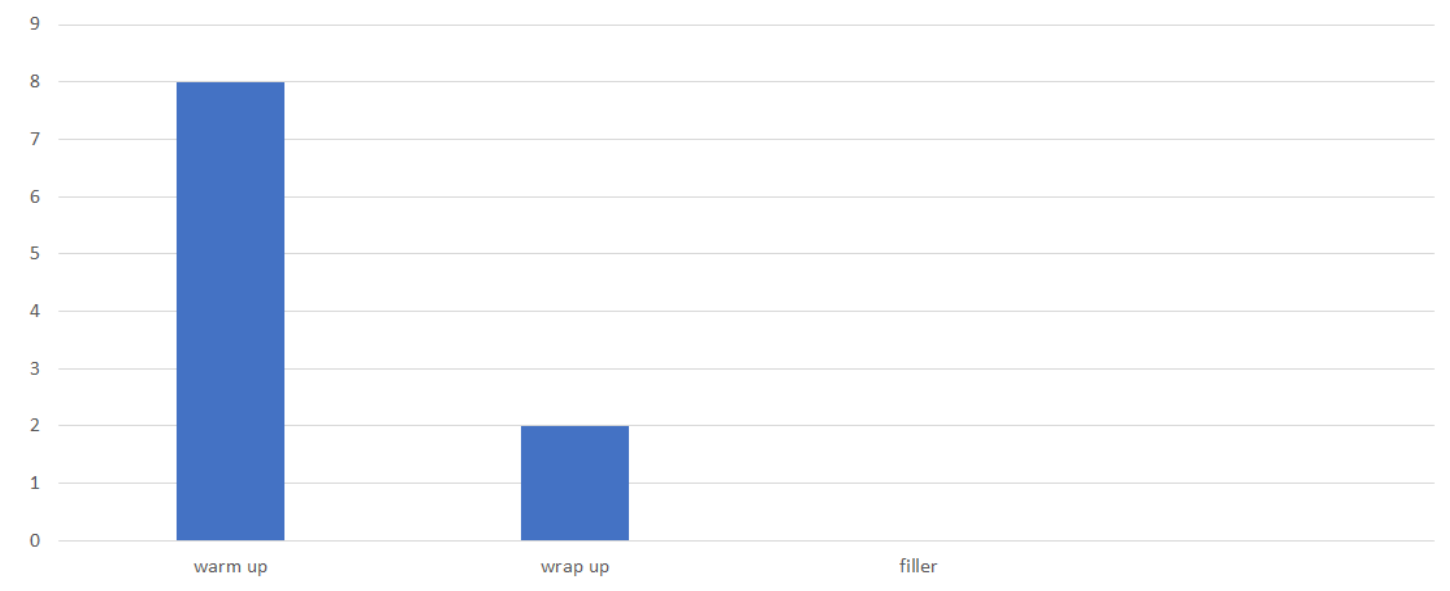

Graph 2 shows that, in general, both the teacher and the students were responsible for deciding together which words went into the vocabox and which didn't. This finding, in turn, emphasizes the learner-centered nature of the intervention in question. For Nunan (1988), learner-centeredness is key to L2 learning, since the learner is central to the decision-making process regarding the content and how it is taught. Such approach leads teachers and learners to inevitably engage in collaborative effort.

It is also worth pointing out here that, given the restrictions in our working memory capacity and our ability to only manipulate a limited number of items at a time (BADDELEY, 2000), the role of the teacher making certain features more salient for learners to focus attention on is paramount in this process. In other words, our data show that the teachers 
assume an active role in guiding learners in the process of selecting what words to learn and that seems to be effective in terms of $L 2$ development.

Graph 2: who chooses words

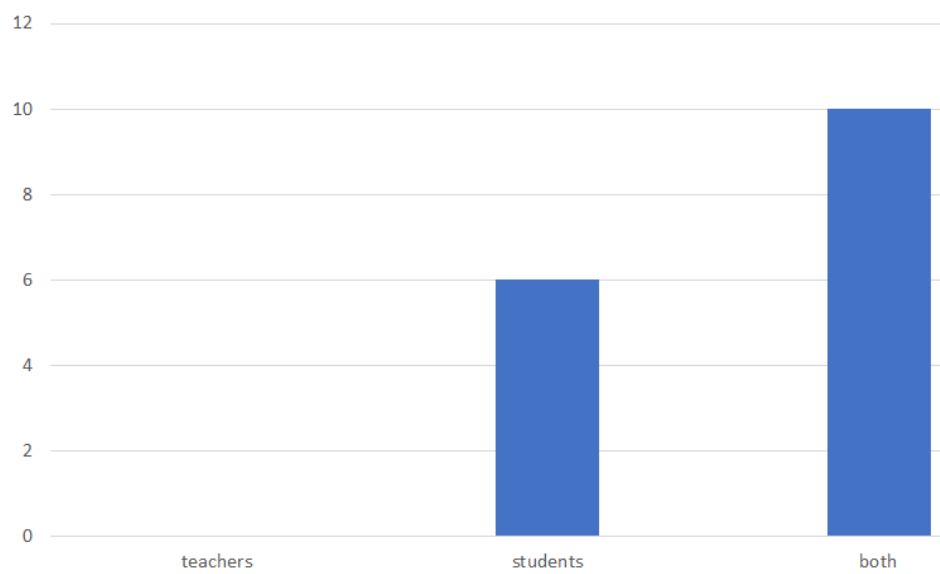

Finally, Graphs 3 and 4 display signs of engagement and disengagement by learners during the Vocabox Experience. Among signs of engagement, the most noticeable were: establishing eye contact with the teacher and/or game mates; laughing; and active participation in the vocabox game. Signs of engagement like the ones reported here may indicate that students are disconnected from the outside world and concentrated in the games, which describes a movement towards a state of flow, as proposed by Csikszentmihalyi (1990). In this sense, gamification seems to be an alternative to generate satisfaction and well-being in learners, increasing their motivation and concentration levels (FADEL et al., 2014).

Graph 3: signs of engagement

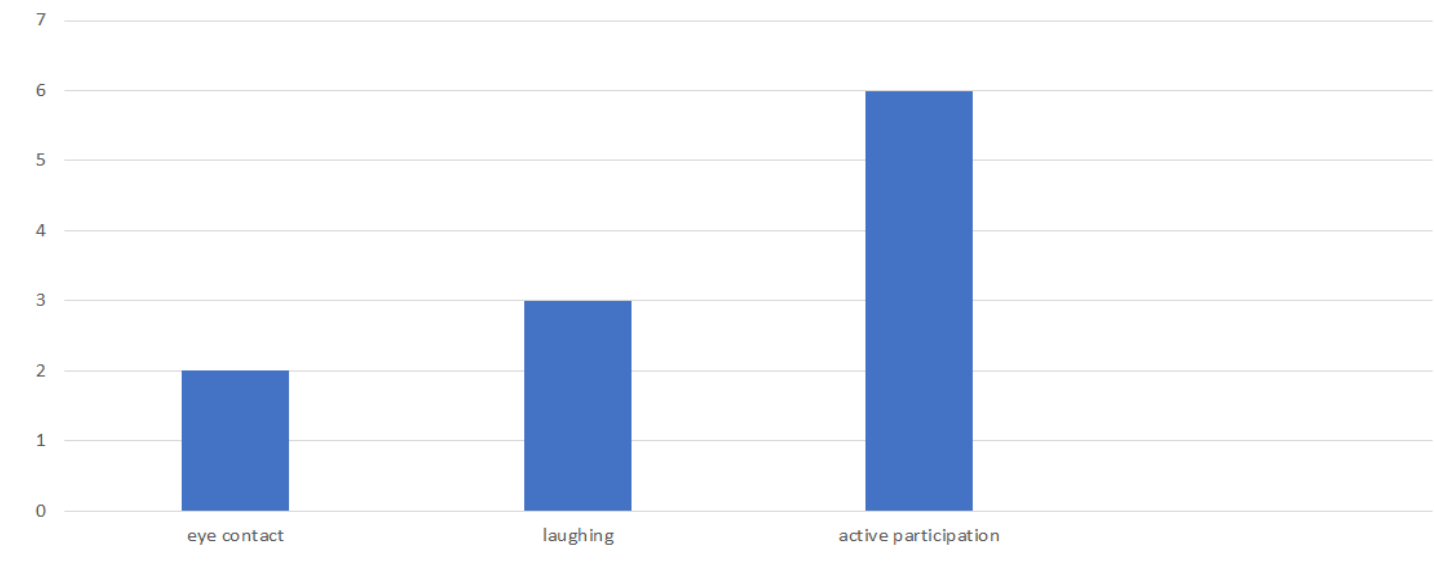


However, signs of disengagement were also observed among learners, which are displayed in Graph 4. These involved cellphone use (mainly texting), parallel talk with peers about subjects not related to the game being played, and yawing.

Graph 4: signs of disengagement

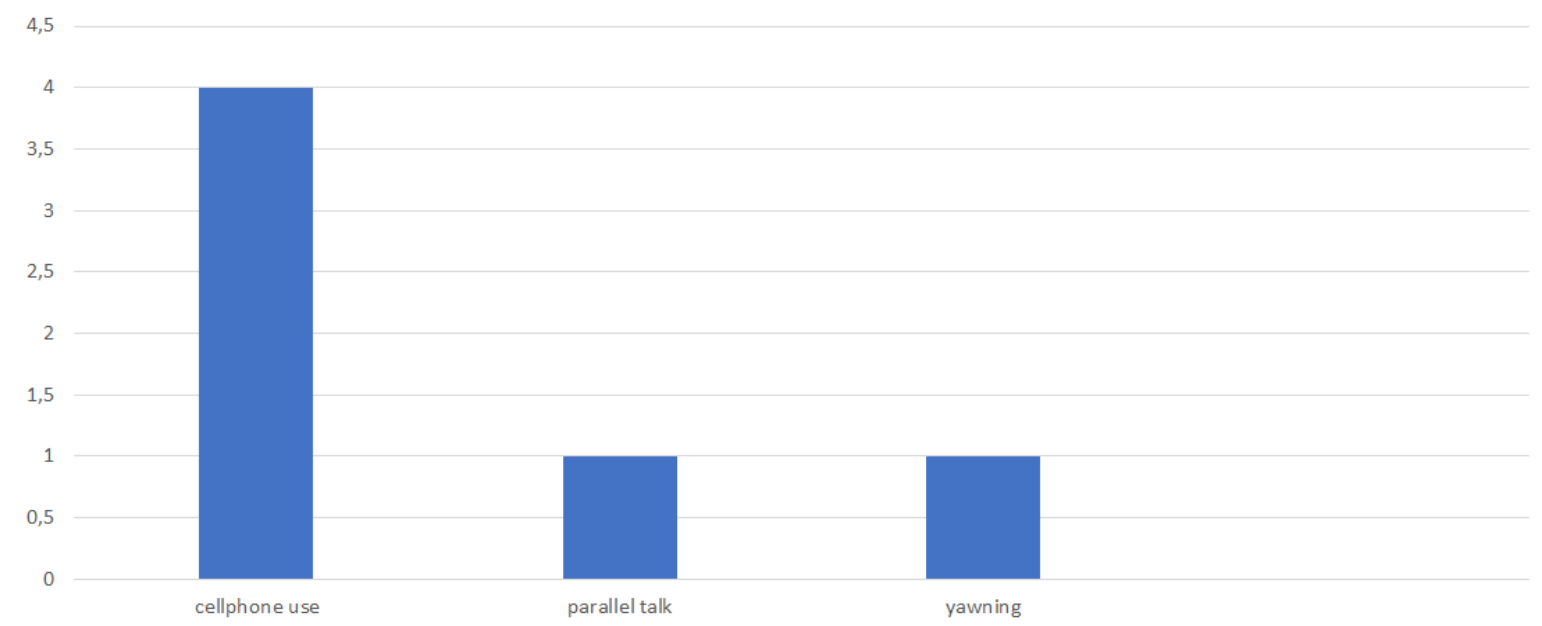

Before moving on, one important point needs to be made about the limitations of observing signs of engagement and disengagement in class. Although eye contact is generally assumed to be a sign of cognitive engagement, it is in fact possible that a learner's eyes are riveted on the game, but his/her thoughts are wandering off. By the same token, cellphone use might not always be a sign of disengagement, since the learner may be using his/her phone to look up the meaning of vocabox words or get help to win the game, for instance. Therefore, conclusions on observed signs of engagement and/or disengagement in our and other studies should be drawn with caution.

Teachers' and Learners' impressions on the outcomes of the Vocabox gamified experience

In order to analyze teachers' and students' impressions on the gamified Vocabox Experience, we designed word clouds representing the most frequent terms and expressions used by teachers and students when evaluating the Vocabox Experience during the focused discussion sessions. Figures 1 and 2 show the main positive aspects mentioned by teachers and students. 
Figure 1: most recurrent positive items in teachers' appraisal of the Vocabox Experience

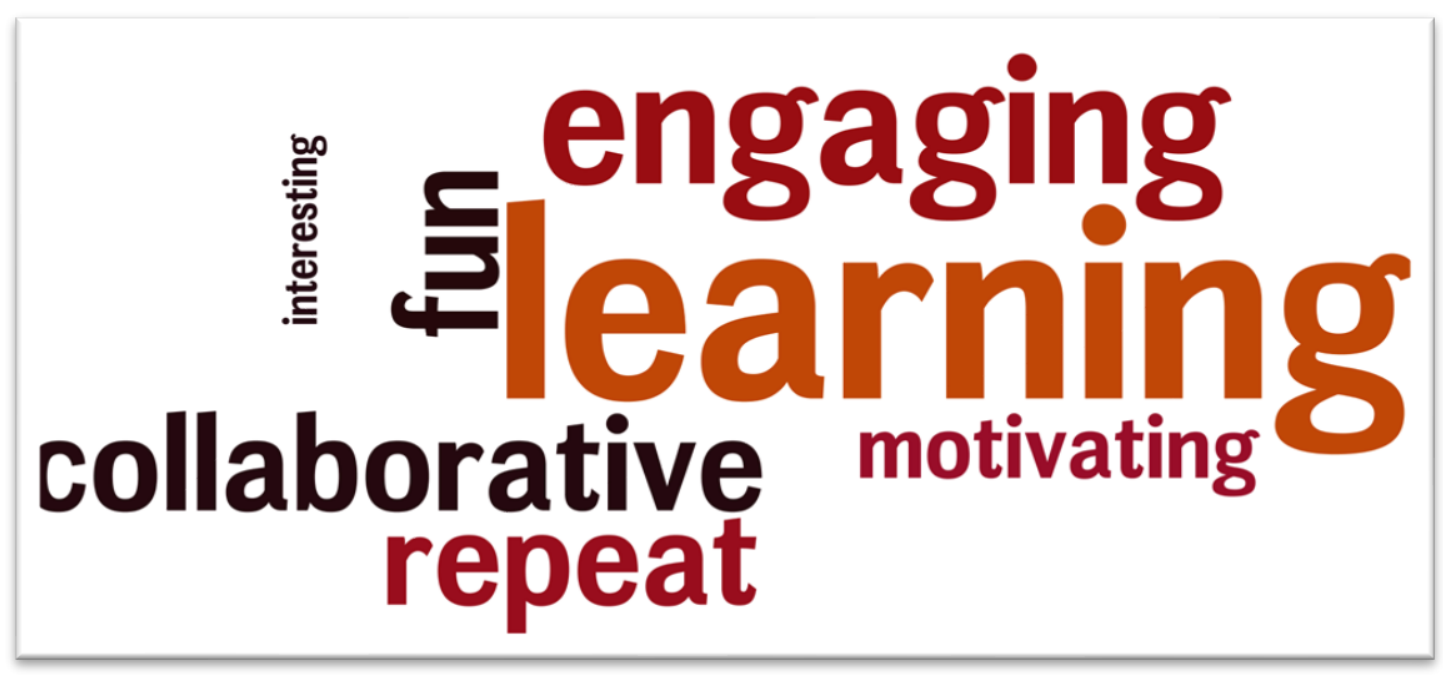

Figure 2: most recurrent positive items in students' appraisal of the Vocabox Experience

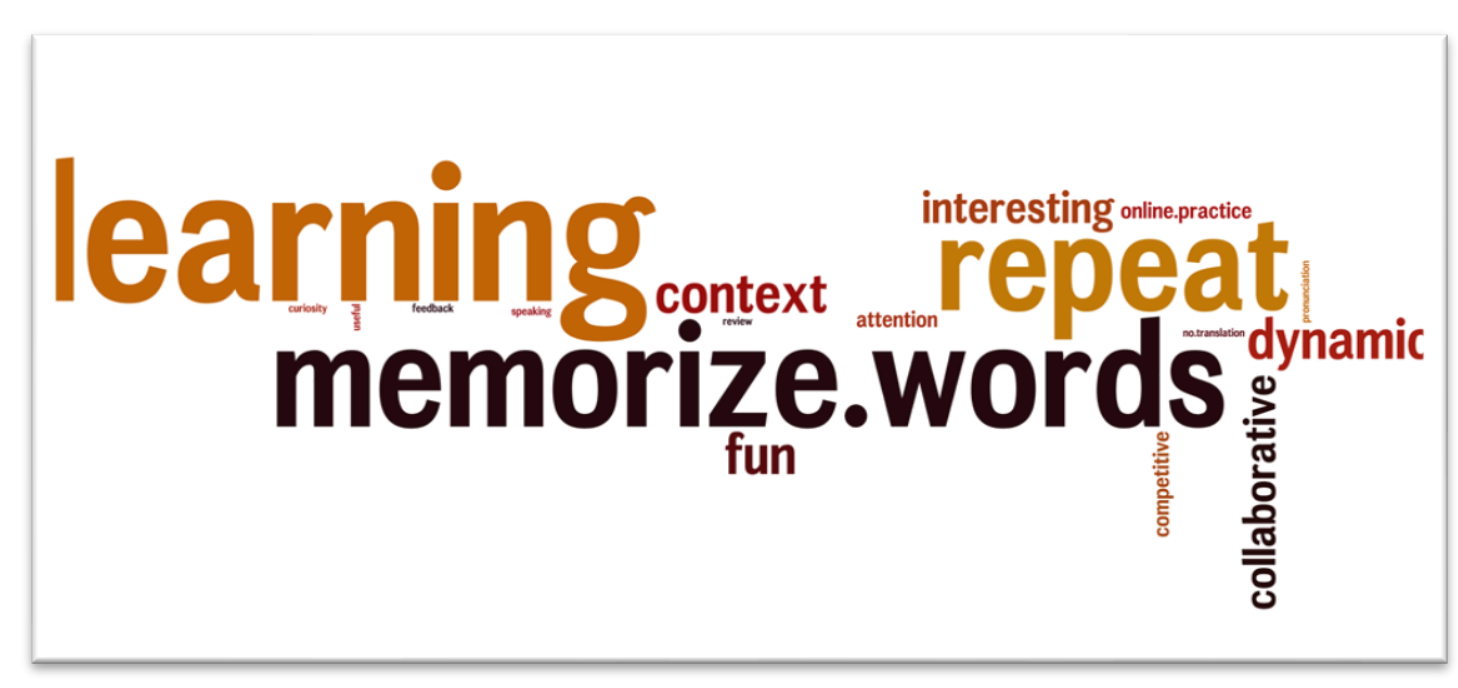

Taking the two word clouds together (Figures 1 and 2), it is noteworthy that "learning" is the biggest word in both clouds, which is, if nothing else, a sign that the implementation achieved its expected result: L2 vocabulary learning. But there is one important difference in that regard. In general, the teachers see the learning process as a whole, from the beginning of the course to its end. As one teacher put it:

They [the students] learn the first words more deeply each time. They learn other meanings, other contexts. The more activities you bring, the more they understand that 
word. And there are words that students start to actively use frequently in class because they want to show that they know much more. ${ }^{5}$

Students, on the other hand, don't necessarily see the process as a whole, but they see vocabulary learning in terms of memorizing words, and perceive the Vocabox games as a means by which to measure how much they have learned. One of the students stated that he/she

noticed a lot of change [in using Vocabox]. I think the fact that we are being stimulated to know this word, and a day later we do activities that always review these new words, really make we memorize them. So, we had two months of remembering words all the time. When we realized, we already knew a lot. ${ }^{6}$

Another important aspect present in both students' and teachers' positive appraisals was the role of repetition in L2 vocabulary learning. As one student put it

The fact that [the Vocabox] is repetitive, for me, is a really big advantage because I have a lot of difficulty with English vocabulary. Actually, I have difficulty with English as a whole. So, for me, the repetition is the only thing that guarantees that I am really going to be able to keep the meaning of that word. ${ }^{7}$

The fact that both teachers and students referred to repetition as something positive in the process of $L 2$ vocabulary learning leads us to inevitably question the role that repeating information as a way to potentialize its retention in long-term memory has. As mentioned previously, our memory system has a limit to the amount of information (in our case, words) that it can manipulate at a given time (BADDELEY, 2000). In this sense, repetition (through gamified tasks) can be viewed as a key element to overcome this processing limitation and potentialize word retention in long-term memory.

Finally, one other aspect that was mentioned by both teachers and students as being positive was collaboration and engagement. As one teacher points out

5 Eles [os alunos] aprendem as primeiras palavras mais profundamente a cada vez. Eles aprendem outros significados, outros contextos. Quanto mais atividades você trouxer, mais elas entenderão essa palavra. E há palavras que os alunos começam a usar ativamente com frequência nas aulas porque querem mostrar que sabem muito mais.

${ }^{6}$ Eu senti muita diferença [ao utilizar o Vocabox], eu acho que o fato de tá estimulando a gente a... tipo, saber dessa palavra e um dia depois fazer atividades que sempre retomam essas palavras novas fazem com que realmente elas vão se fixando, então foram dois meses de relembrar palavras o tempo todo e aí quando a gente foi ver, já tinha um monte.

${ }^{7} \mathrm{E}$ o fato de ser repetitivo pra mim é uma super vantagem porque eu tenho muita dificuldade com vocabulário inglês, na verdade eu tenho dificuldade com inglês como um todo. Então, pra mim, assim, o fato de ser repetitivo é a única coisa que garante que eu realmente vou conseguir gravar o significado daquela palavra. 
Engagement was something essential for my course, especially for the group that was observed, the B1 group. A sense of belonging was much more present after the [Vocabox] activity started to go somewhere. [...] In all activities, students were super engaged, they loved doing the activities, but did not write words to put in the Vocabox. But after they got the hang of writing words and putting them there, closer bonds were formed, to say so. ${ }^{8}$

As Vianna et al. (2013) emphasize, collaboration can represent an important learning opportunity, since learners work together towards a common goal and face the challenge of vocabulary learning collectively.

Let us now move to the negative aspects of the Vocabox Experience mentioned by teachers and students during their focused discussion sessions. Figure 3 is a cloud representation of the most frequent negative words in the teachers' speech.

Figure 3: most recurrent negative items in teachers' appraisal of the Vocabox Experience.

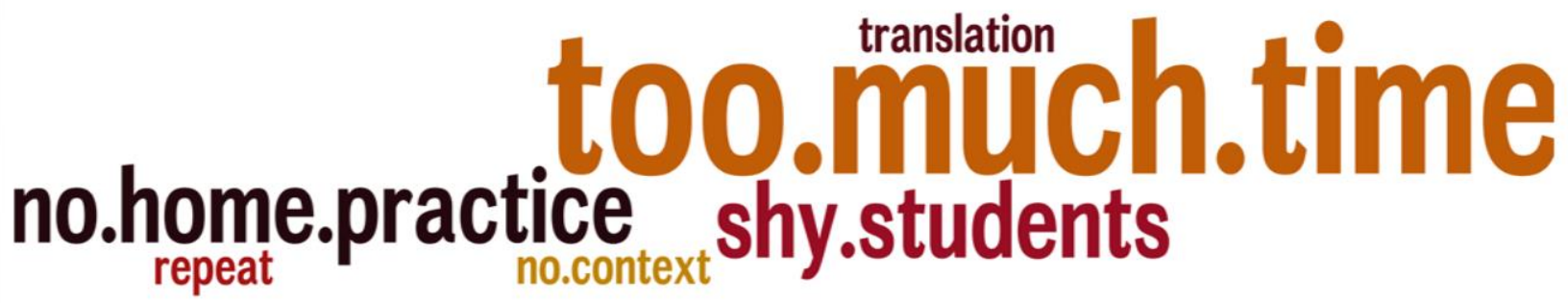

In general, teachers picture the most negative aspect of the Vocabox Experience being the fact that it is too time consuming, both in terms of class planning and implementation.

It [the Vocabox activity] ends up taking too much time because it's something interesting, that students enjoy a lot. If I did it at the beginning of class, it took like 30 or 40 minutes of class. If I did it at the end of class, it ended up going beyond the class hours. ${ }^{9}$

${ }^{8} \mathrm{O}$ engajamento é, foi algo essencial pro meu curso, principalmente pra turma que foi observada, que foi a turma de B1, que criou-se um coleguismo muito maior depois que a atividade foi começando a tomar um rumo. [...] Todas as atividades eles estavam super engajados, eles adoravam fazer isso, só que não escreviam pra colocar lá, mas depois que eles foram pegando esse jeito de escrever e colocar os laços foram se estreitando, digamos assim.

${ }^{9}$ Acaba tomando muito tempo, por que é uma coisa interessante, que eles gostam muito, então se eu fizesse no início da aula, quando eu via, tomava uns 30, 40 minutos da aula, se eu fizesse no final pegava um pedaço da aula de outro professor. 
Another aspect mentioned by the teachers is the lack of engagement by students in terms of home practice.

Something [else] I found to be a little hard is to have students go to Vocabulary.com to practice at home. They participate a lot in class, they practice a lot in class, but even if we send many emails asking them to practice at home during the week, when they get to class, we know that they did not practice. We see on Vocabulary.com that they did not practice. It's really frustrating sometimes. We keep asking, and asking, and asking, and they do not participate. ${ }^{10}$

As for the negative aspects mentioned by students, Figure 4 shows that the most frequent negative words in the students' speech were related to the fact that, in their view, vocabox words did not provide them with a context within which to use and, therefore, better learn these words.

Figure 4: most recurrent negative items in students' appraisal of the Vocabox Experience

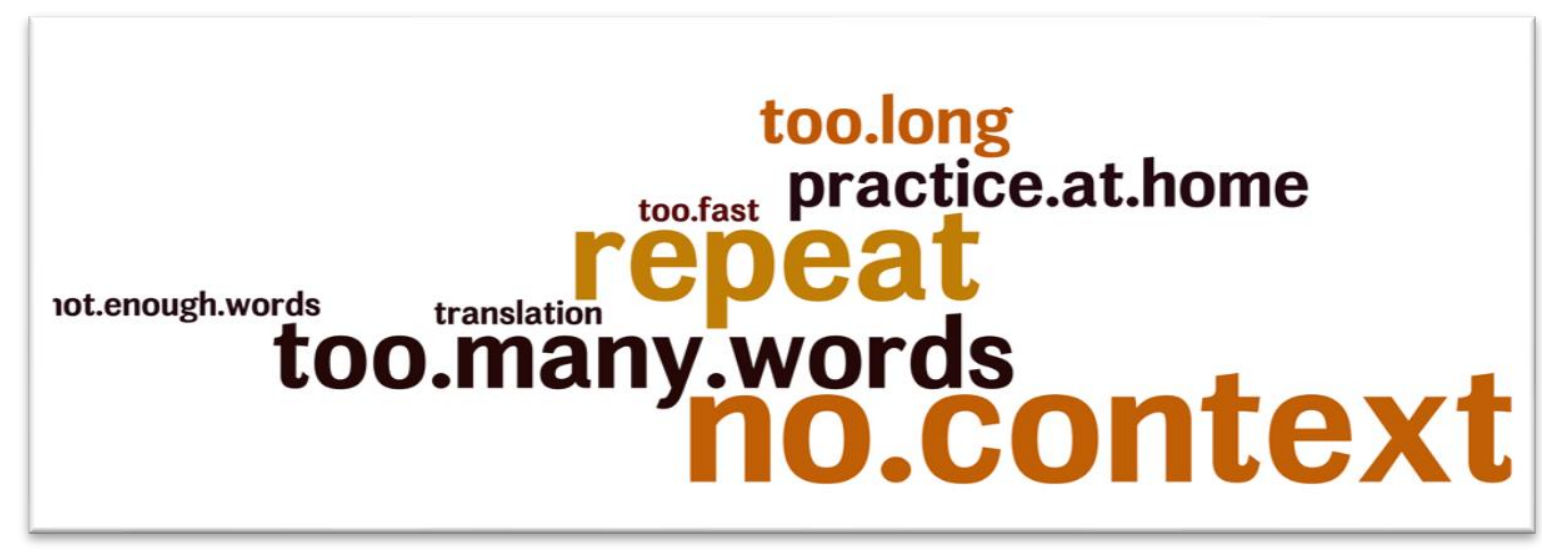

According to one student

The negative aspect of Vocabox, I think, is that sometimes you will look at a word later, when there is no context, and you have to make an effort to remember where that came from. If there was a way to have the word in the Vocabox along with some reference about from where that word comes from, how it was suggested for the Vocabox, maybe assimilation of that word would be better. ${ }^{11}$

\footnotetext{
${ }^{10}$ A outra coisa que eu achei um pouco difícil também é fazer com que os alunos entrem no vocabulary.com pra praticar em casa. Eles... eles participam muito na sala de aula, eles praticam muito na sala de aula, mas mesmo que a pessoa mande muitos e-mails, 'gente, pratiquem', durante a semana, quando chega na sala de aula, a gente sabe que eles não praticaram e a gente vê no vocabulary.com que eles não praticaram e mesmo... e é muito frustrante às vezes e a gente fica pedindo, pedindo, pedindo e eles não participarem.

${ }^{11} \mathrm{O}$ aspecto negativo que eu acho do Vocabox é que tem horas que você olha a palavra depois no Vocabox, quando não tem o contexto, você tem que se esforçar pra se lembrar de onde veio aquele contexto. Então se, junto
} 
We speculate here, based on the teachers' comments in their focused discussion session, that the lack of context pointed out by the students may lead them to resort to translation to a greater extent. In fact, translation was mentioned by a few students as a negative aspect of the pedagogical implementation. Therefore, teachers should have that in mind when planning their Vocabox Experience, i.e. the fact that some words require more of a context to be understood than others.

From the negative aspects exposed, some ideas to improve the experience can be outlined. Considering that "knowing a word well involves knowing several aspects of covering the meaning and use of the word" (NATION, 2006, p. 448), teachers should be aware of the fact that some words must be learned considering the contexts in which they usually emerge. Some techniques to avoid translation should also be considered along the execution of games, as well as time should be controlled to avoid fatigue and cognitive disengagement.

An interesting fact is that although repetition was seen by students and teachers as a positive aspect of the Vocabox Experience, as we discussed before, it was surprisingly mentioned as a negative aspect as well. However, as we can see in the following excerpt, what seems to have been the problem is that the implementation involved repeating the same vocabox words every class, so it wasn't repetition as a learning process which seems to have bothered the students, but how repetitive the implementation became as a whole.

The disadvantage that I found was that it was really repetitive. Every class, always the same words. It would be nice if it were the words of the week, or the month, something like that, instead of being the whole course. ${ }^{12}$

One final aspect that students mentioned as a potential drawback of the Vocabox Experience was the fact that there were too many words to be learned by the end of the course, and this seems to have generated some anxiety and burden for the students.

I think a negative point regarding Vocabox is the amount of words. There are a lot of words. Usually, here at the IsF course, people have an academic routine and end up not having a lot of time to review all of the words. ${ }^{13}$

com aquela palavra do Vocabox você pudesse ter alguma referência de onde ela foi, como é que ela foi sugerida, talvez a assimilação daquela palavra fosse melhor.

${ }^{12}$ A desvantagem que eu achei que foi muito repetitivo, toda aula era sempre as mesmas palavras, seria legal se fosse, tipo, as palavras da semana, as palavras do mês, uma coisa assim. Ao invés de ser o curso todo.

13 Um ponto negativos em relação ao Vocabox, eu achei a quantidade, tem muita quantidade de palavras, e geralmente aqui no curso do IsF, como a galera tem uma rotina acadêmica, acaba que não tem muito tempo de revisar todas, e isso é até um pouco, pra mim foi um aspecto negativo né, a questão do tempo corrido e não poder analisar todo o Vocabox. 
Taking the results reported in this section together, we can notice that students and teachers have highlighted both positive and negative aspects of the gamified intervention in question. As a logical next step, it would be interesting to measure vocabulary learning outcomes to compare and contrast to the students' and teachers' impressions. However, that objective was beyond the scope of this study, and will be regarded as a limitation in the Conclusions section, which follows.

\section{Conclusions}

Our aim in this paper was to report a study which investigated a gamified vocabulary teaching and learning intervention, called the Vocabox Experience, which was implemented with students in the context of the Languages without Borders program. For this investigation, the data obtained from the observation grids and focused discussions were organized in word clouds and graphs to enable a better visualization of positive and negative aspects pointed out by teachers and students, as well as the signs of engagement and disengagement observed in the first phase of the collection.

Our results reveal that there is a variety of impressions reported from both teachers and students concerning their impressions about the vocabulary learning in a gamified experience. The word clouds show that both groups pointed out positive and negative aspects that must be taken into account. Considering the positive feelings, it is clear that learning is a central aspect for both groups. However, while teachers tend to understand learning - in this experience - as a process which involves collaboration and motivation during the execution of the games, some students apparently associate vocabulary learning to the idea of memorization of words by repetition. Nevertheless, despite the differences in which each group perceived the way the games would enable vocabulary learning, it remains a clear fact that both of them seem to consider that Vocabox experience achieved its purpose of boosting L2 vocabulary learning.

Although it is the most emphasized aspect, learning is not the only positive impression shared by teachers and students. They both see the Vocabox gamified experience as a funny practice, and students also point out how dynamic it is. Both groups highlighted the collaborative aspect of the process, although some students also pointed the competition as an element of it. The emergence of both contrastive concepts show the variety of games that teachers used to increment the Vocabox experience. The other aspects that teachers pointed out were related to engagement and motivation of the students when participating of the games. This perception is supported by the graph with the signs of engagement observed during the activities. In their turn, some students highlighted the possibility of learning in context as a positive aspect of the experience. 
On the other hand, the negative aspects emphasized by teachers and students show that both groups perceive the lack of homework as problematic in this experience, and the students consider that the learning of vocabulary in this experience is out of any context. Teachers agree with this view and also point out that the use of Vocabox consumes considerable class time. Teachers also see the students' needs of translation as negative to the learning process, while some students considered the burden of vocabulary to be learned too high. Some students also see as a negative point the repetition of the same words along the whole course, and some of them consider, as the teachers do, translation as a problem during the execution of the games.

Despite these encouraging findings, this study does not go without limitations. First, vocabulary learning was not measured in terms of increase in pre and post-test scores. Future research should include such data to add statistical value to the observations and qualitative reports. Second, signs of engagement and disengagement were only observed and not measured in our study. Future investigations could contribute by diversifying the way in which they look at engagement, perhaps even including eye-tracking and other online techniques.

All in all, we hope this study contributes to the discussion on gamification and L2 vocabulary teaching and learning, ultimately helping teachers to reflect on their vocabulary teaching and boost their gaming repertoire.

\section{References}

BADDELEY, A. The episodic buffer: a new component of working memory? Trends in cognitive sciences, v. 4, n. 11, p. 417-423, 2000. https://doi.org/10.1016/S1364-6613(00)01538-2

CSIKSZENTMIHALYI, M. Flow: The Psychology of Optimal Experience. New York: Harper Perennial, 1990.

DETERDING, S.; DIXON, D.; KHALED, R.; NACKE, L. From game design elements to gamefulness: defining "gamification". In: Proceedings of the 15th International Academic MindTrek Conference: Envisioning Future Media Environments (MindTrek '11), 2012. https://doi.org/10.1145/2181037.2181040

FADEL, L. M.; ULBRICHT, V. R.; BATISTA, C. R.; VANZIN, T. (orgs.). Gamificação na Educação. São Paulo, Pimenta Cultural, 2014.

LEWIS, M. Implementing the lexical approach: Putting theory into practice, v. 3, n. 1, p. 223-232, 1997.

MILLER, G. The magical number seven, plus or minus two: some limits on our capacity for processing information. Psychological Review, v. 63, n. 2, p. 81-97, 1956. https://doi.org/10.1037/h0043158 
NATION, P. Learning Vocabulary in Another Language. Cambridge: Cambridge University Press. 2001. https://doi.org/10.1016/B0-08-044854-2/00635-0

NATION, P. Second language vocabulary. In: K. Brown (ed.) Encyclopaedia of Language and Linguistics, 2nd Ed. Oxford: Elsevier. Vol 13: 448-454, 2006.

NATION, P. Research into practice: Vocabulary. Language Teaching, v. 44, n. 4, p. 529-539, 2011. https://doi.org/10.1017/CBO9781139524506

NUNAN, D. Research methods in language learning. Cambridge university press, 1992.

NUNAN, D. The Learner-Centered Curriculum. Cambridge University Press, 1988. https://doi.org/10.1017/CBO9781139524506

SEPEHR, S.; HEAD, M. Competition as an element of gamification for learning: an exploratory longitudinal investigation. In Proceedings of the First International Conference on Gameful Design, Research, and Applications (p. 2-9). ACM, 2013. https://doi.org/10.1145/2583008.2583009

UR, P.; WRIGHT, A. Five-Minute Activities: a resource book of short activities. Cambridge University Press, 2007.

VIANNA, Y.; VIANNA, M.; MEDINA, B.; TANAKA, S. Gamification, Inc. Como reinventar empresas a partir de jogos. MJV Press, 116 p. (e-book), 2013.

WAJNRYB, R. Classroom observation tasks: A resource book for language teachers and trainers. Cambridge: Cambridge University Press, 1992.

ZICHERMANN, G.; CUNNINGHAM, C. Gamification by design: Implementing game mechanics in web and mobile apps. O'Reilly Media, Inc, 2011.

Recebido em: 08/06/2019

Aceito em: 09/10/2019 